\title{
Tibial Tuberosity Fracture (Type III-B) in Adolescents: Case Report
}

\author{
Ricardo Monreal* \\ Centro Médico MEDEX, República de Panamá 3065 2do piso, San Isidro, and Clínicas Maison de Santé, South America
}

Submission: June 21, 2017; Published: July 03, 2017

*Corresponding author: YRicardo Monreal, Centro Médico MEDEX, República de Panamá 3065 2do piso, San Isidro, and Clínicas Maison de Santé, Ave. Chorrillos 171, Chorrillos. Lima, Peru, South America, Email: rmonreal59@yahoo.es

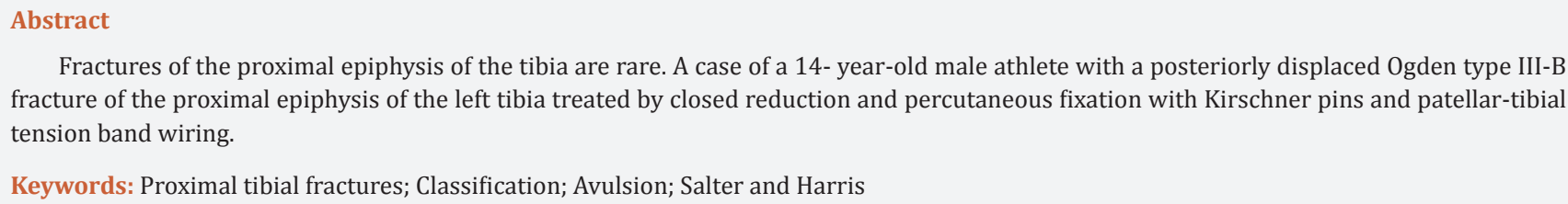

\section{Introduction}

Tibial tuberosity avulsion fractures are rare adolescent injuries with a reported incidence ranging from $0.4 \%$ to $2.7 \%$ [1]. These avulsion injuries predominantly occur in athletic males as the tibial physis begins to fuse before skeletal maturity, which occurs near 14 - 17 years of age [2]. Classification of tibial tubercle fractures has evolved since they were first described in 1976. Initially, the Watson-Jones classification detailed types I, II and III. Then, Ogden modified the classification to better define the extent of injury and amount of displacement or comminution by adding A and B subsets to those types [3]. Type IV was added by Ryu and Debenham to describe an avulsion fracture of the entire proximal tibial epiphysis [4]. Subsequently, type V was introduced to the classification system by McKoy et al. [1] to describe their experience with a patient exhibiting both a type IIIb and type IV injury. Frankl et al. [5] suggested Subset C for type I fractures with associated patellar tendon tears. The goal of treatment is anatomical reduction and stabilization in order to prevent significant soft tissue injury, malunion, and growth arrest.

\section{Case Presentation}

A 14-year-old male experienced sudden left knee pain with 'a pop' when he took-off for a long jump off his left leg. The left knee was held in $110 \circ$ of flexion with inability to extend the knee. On examination, there was swelling over the proximal tibia and tenderness on the anterolateral part of the proximal end of the tibia. No neurovascular impairment was detected. From the plain radiographs a displaced flexion type Ogden classification type III-B fracture of the proximal tibia [6] was identified (Figure 1).

Two hours after admission, under general anesthesia, a closed reduction and percutaneous fixation with Kirschner pins and patellar-tibial tension band wiringand stability of the fracture was confirmed using image intensifier (Figure 2). A circumferential cast in $5 \circ$ of knee flexion was applied. Six weeks after injury, fracture position was satisfactory with radiographic evidence and the cast was removed, encouraging active range of motion of the knee. Fracture healing in a good position and full range of motion were achieved 10 weeks after injury.

\section{Conclusion}

In the present report a Type III-B of tibial tuberosity avulsion fractures is described in a 14-year-old male who was injured in jumping sport. Type III tibial tuberosity fractures demonstrate anterior intra-articular fracture extension through the physis and epiphysis into the knee. The tuberosity and the anterior epiphysis remain as a unit. A type IIIB designation (Figure 1 ) is given if the avulsion results in comminution $[2,6]$. Open reduction and internal fixation is performed for types IIB, IIIA, IIIB, and IV tibial tuberosity avulsion fractures. Several methods of fixation have been reported, but most authors recommend tension band wiring or cannulated screw fixation of the avulsed fragment (Figure 2) [1,3,7]. 


\section{Open Access Journal of Surgery}

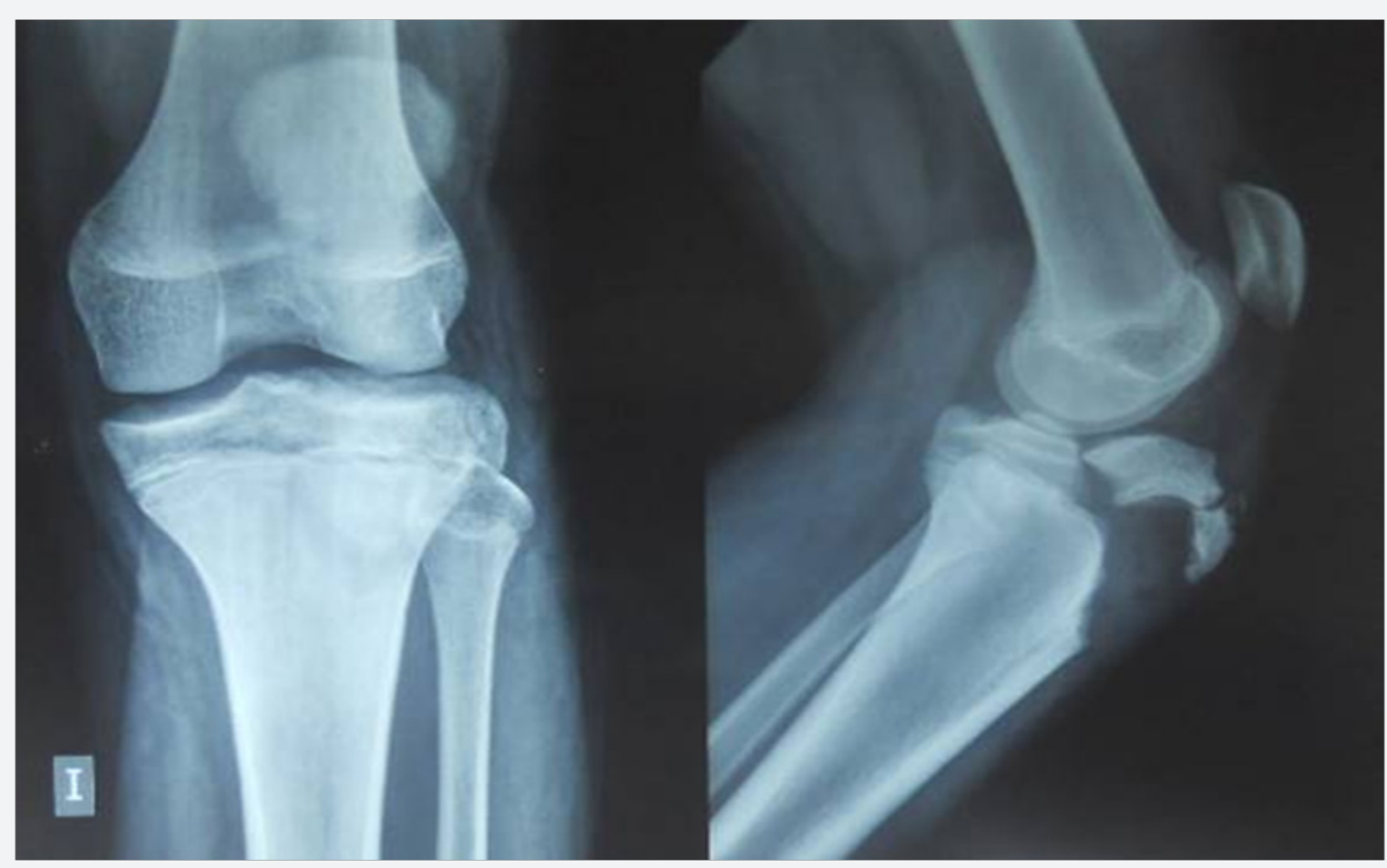

Figure 1: In Type III-B tibial tuberosity fractures there are an anterior intra-articular extension through the physis and epiphysis with comminution.

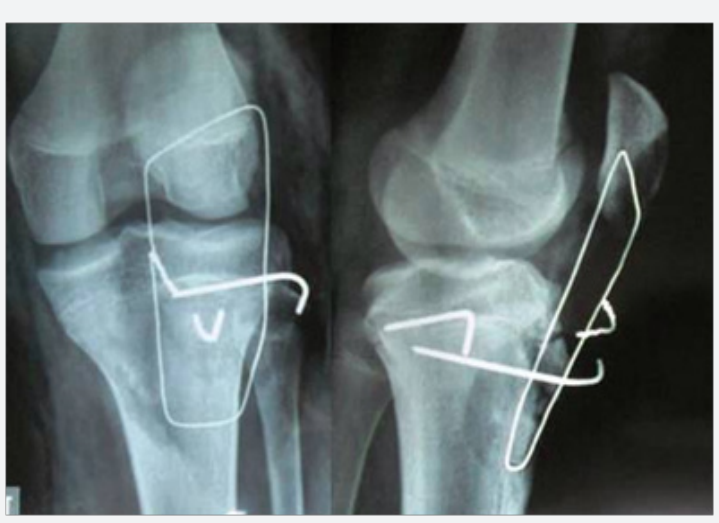

Figure 2: Type III-B fracture after closed reduction and percutaneous fixation with Kirschner pins and patellar-tibial tension band wiring.

\section{Reference}

1. Alomi YA, Alghamdi SJ, Alattyh RA (2015) Strategic Plan of General Administration of Pharmaceutical Care at Ministry of Health in Saudi Arabia 2012 - 2022. J Pharm Pharm Scien 1(13): 1-8.

2. Alomi Y. National Pharmacy Practice Programs at Ministry of Health in Saudi Arabia. J Pharm Pharm Scien 1(12): 17-18.

3. Alomi Y (2015) National antimicrobial stewardship program in Saudi Arabia: Experiences and future vision. Clin Pharmacol Biopharm 4(4): 49.

4. Bin Abdulhak AA, Al Tannir MA, Almansor MA, Almohaya MS, Onazi AS, et al.(2011) Non-prescribed sale of antibiotics in Riyadh, Saudi Arabia: A Cross-Sectional Study. BMC Public Health 11(1): 538.

5. Aljadhey H, Assiri GA, Mahmoud MA, Al-Aqeel S, Murray M (2015) Self- medication in central Saudi Arabia: Community pharmacy consumers' perspectives. Saudi Med J 36(3): 328-334.

6. Emeka PM, Al-Omar M, Khan TM (2014) Public attitude and justification to purchase antibiotics in the Eastern region Al Ahsa of Saudi Arabia. Saudi Pharm J 22(6): 550-554.

7. Lakshmana Gowda K, Marie MAM, Al-Sheikh YA, John J, Gopalkrishnan S, et al. (2014) A 6-year surveillance of antimicrobial resistance patterns of Acinetobacter baumannii bacteremia isolates from a tertiary care hospital in Saudi Arabia during 2005-2010. The Libyan journal of medicine.

8. Aly M, Balkhy HH (2012) The prevalence of antimicrobial resistance in clinical isolates from Gulf Corporation Council countries. Antimicrob Resist Infect Control 1(1): 26.

9. Zowawi HM (2016) Antimicrobial resistance in Saudi Arabia: An urgent call for an immediate action. Saudi Med J 37(9): 935-940.

10. Yezli S, Shibl AM, Livermore DM, Memish ZA. Prevalence and antimicrobial resistance among Gram-negative pathogens in Saudi Arabia. J Chemother 26(5): 257-272.

11. Chaudhry LA, Al-Tawfiq JA, Zamzami MM, Al-Ghamdi SA, Robert AA (2016) Antimicrobial susceptibility patterns: A three-year surveillance study in a rehabilitation setting. Pan Afr Med J. 23: 214

12. Al Yousef SA (2016) Surveillance of antibiotic-resistant bacteria in King Khalid Hospital, Hafr Al-Batin, Saudi Arabia, during 2013. Jundishapur J Microbiol.

13. Al Bshabshe A, Joseph MRP, Hussein A Al, Haimour W, Hamid ME (2016) Multidrug resistance Acinetobacter species at the intensive care unit, Aseer Central Hospital, Saudi Arabia: A one-year analysis. Asian Pac J Trop Med 9(9): 903-908.

14. Alam MZ, Alam Q Jiman-Fatani AA, Ahmed Shukri H, Haque A (2017) A surveillance study on the prevalence and antimicrobial resistance 
pattern among different groups of bacteria isolated from Western Province of Saudi Arabia.

15. Haseeb A, Faidah HS, Bakhsh AR, Malki WH Al, Elrggal ME, et al. (2016) Antimicrobial resistance among pilgrims: A retrospective study from two hospitals in Makkah, Saudi Arabia. Int J Infect Dis.

16. Neidell MJ, Cohen B, Furuya Y, Hill J, Jeon CY, et al. (2012) Costs of healthcareand community-associated infections with antimicrobialresistant versus antimicrobial-susceptible organisms. Clin Infect Dis.

17. Pogorzelska-Maziarz M, Herzig CTA, Larson EL, Furuya EY, Perencevich EN (2015) Implementation of Antimicrobial Stewardship Policies in U.S. Hospitals: Findings from a National Survey. Infect Control Hosp Epidemiol.

18. Howard P, Pulcini C, Levy Hara G, West RM, Gould IM, et al. (2014) An international cross-sectional survey of antimicrobial stewardship programs in hospitals. J Antimicrob Chemother 70(4): 1245-1255.

19. Trivedi KK, Dumartin C, Gilchrist M, Wade P, Howard P (2014) Identifying best practices across three countries: hospital antimicrobial stewardship in the United Kingdom, France, and the United States. Clin Infect Dis 59 Suppl 3: S170-178.

20. Enani MA (2016) The antimicrobial stewardship program in Gulf Cooperation Council (GCC) states insights from a regional survey. J Infect Prev 17(1): 16-20.
21. Amer MR, Akhras NS, Mahmood WA, Al-Jazairi AS (2013) Antimicrobial stewardship program implementation in a medical intensive care unit at a tertiary care hospital in Saudi Arabia. Ann Saudi Med 33 (6):54754.

22. Aldeyab MA, Kearney MP, Scott MG, Aldiab MA, Alahmadi YM (2012) An evaluation of the impact of antibiotic stewardship on reducing the use of high-risk antibiotics and its effect on the incidence of Clostridium difficile infection in hospital settings. J Antimicrob Chemother 67(12): 2988-2996.

23. Alawi MM, Darwesh BM (2016) A stepwise introduction of a successful antimicrobial stewardship program: Experience from a tertiary care university hospital in Western, Saudi Arabia. Saudi Med J 37(12): 1341-1349.

24. AlAwdah L, AlShahrani D, AlShehri M, AlFawaz T, ElSidig N (2015) Antimicrobial stewardship program in a pediatric intensive care unit of a tertiary care children's hospital in Saudi Arabia-a pilot study. Antimicrob Resist Infect Control 4(Suppl 1): P173.

25. CDC (2014) The Core Elements of Hospital Antibiotic Stewardship Programs. Atlanta, GA US Dep Heal Hum Serv CDC 1-24.

26. Nagel JL, Stevenson JG, Eiland EH, Kaye KS (2014) Demonstrating the value of antimicrobial stewardship programs to hospital administrators. Clin Infect Dis 59 Suppl 3: S146-153.

\section{Your next submission with Juniper Publishers} will reach you the below assets

- Quality Editorial service

- Swift Peer Review

- Reprints availability

- E-prints Service

- Manuscript Podcast for convenient understanding

- Global attainment for your research

- Manuscript accessibility in different formats

( Pdf, E-pub, Full Text, Audio)

- Unceasing customer service

Track the below URL for one-step submission https://juniperpublishers.com/online-submission.php 